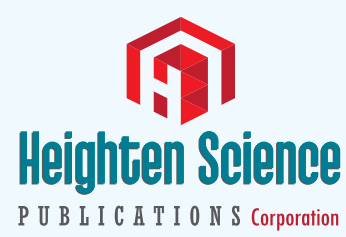

ISSN

2640-284X
*Address for Correspondence: Ayfer Gözü Pirinççioğlu, Department of Pediatrics, Faculty of Medicine, University of Dicle, 21280, Diyrabakir, Turkey, Email: ayfergozu@dicle.edu.tr; ayfergozu@hotmail.com

Submitted: 27 June 2017

Approved: 28 August 2017

Published: 29 August 2017

Copyright: @ 2017 Pirinççioğlu AG, et al. This is an open access article distributed under the Creative Commons Attribution License, which permits unrestricted use, distribution, and reproduction in any medium, provided the original work is properly cited

Keywords: Beta-thalassemia major; Secondary hyperparathyroidism; Parathyroid dysfunction

Check for updates
Research Article

\section{Parathyroid Functions in Thalassemia Major Patients}

\author{
Ayfer Gözü Pirinççioğlu ${ }^{1 *}$, Deniz Gökalp ${ }^{2}$ and Murat Söker ${ }^{1}$ \\ 'Department of Pediatrics, Faculty of Medicine, University of Dicle, Turkey \\ ${ }^{2}$ Department of Endocrinology, Acıbadem Hospital, Turkey
}

\section{Abstract}

Background: Hypoparathyroidism is well known to occur in thalassemia major patients, but it is thought to be uncommon and its incidence is considered to be decreasing with improvements in chelation therapy. The objective of this study was to assess the prevalence of parathyroid dysfunction in the first decade of life of the patients with thalassemia major.

Patients and Methods: Ninety children with beta-thalassemia major ( 55 males and 35 females) with a mean age of $7.17 \pm 3.78$ years ( $1-13$ years) and age and sex matched control group of 60 healthy children ( 36 males and 24 females) with a mean age $6.98 \pm 3.66$ years $(1-13)$ years. Serum parathyroid hormone (PTH), serum total Calcium (Ca), serum phosphorus (P), serum alkaline phosphatase (ALP), serum 25-hydroxyvitamin D (25-OHD) and serum ferritin levels were measured.

Result: PTH levels were higher than normal range in $23(25.6 \%)$ patients with a mean value of $75.2 \pm 31.3 \mu \mathrm{g} /$ $\mathrm{mL}$ compared to those having normal range level $(35.3 \pm 15.2 \mu \mathrm{g} / \mathrm{mL})$. Ca levels were found low in 11 patients (12.2\%), and $\mathrm{P}$ levels were found high in $2(2.22 \%)$ and low in 4 (4.44\%) patients while high ALP levels were found in $6(6.67 \%)$ patients. $25-\mathrm{OHD}$ levels were low in all patients with a mean value of $24.95 \pm 5.82$.

Conclusion: Reports in the literature indicate that parathyroid dysfunction due to iron overload generally occurs in 2nd or 3rd decade of patients with thalassemia major. However, our study shows that PTH due to iron overload may develop in a significant number of thalassemia major patients, therefore, all thalassemics should be carefully watched for endocrine organ function such as hyperparathyroidism might occur even in the first decade of the patients with thalassemia major.

\section{Introduction}

Beta-thalassemia major is an autosomal recessive hereditary anemia, which is incurable, caused by defective synthesis of hemoglobin, ineffective erytropoiesis and rapid erythrocyte breakdown, resulting in advanced heart failure and death in early childhood. It is characterized by reduced synthesis of $\beta$-globin chain and first described by Cooley and Lee [1]. The homozygous state results in severe anemia, which needs regular blood transfusion. The combination of transfusion and chelation therapy has dramatically extended the life expectancy of thalassemic patients who can now survive into their fourth and fifth decades of life [2,3]. However, frequent blood transfusion in turn can lead to iron overload which may causes hypogonadism, diabetes mellitus, hypothyroidism, hypoparathyroidism and other endocrine abnormalities [4]. In recent years, several authors reported a high incidence of endocrine abnormalities in children, adolescents and young adults suffering from thalassemia major. Nevertheless the incidence of the various endocrinopathies shows varieties among different series of the patients due to a mixture of reasons other than iron overloads [5].

We have previously reported the bone mineral density [6], and the status of thyroid functions [7], in children with beta-thalassemia major. The current study aims to report the prevalence of parathyroid dysfunction, and to characterize its role in bone loss related to thalassemia by measuring serum calcium $(\mathrm{Ca})$, phosphorus $(\mathrm{P})$, alkaline 
phosphatase (ALP), 25-hydroxyvitamin D (25-OHD), parathyroid hormone (PTH) and ferritin levels in children with beta-thalassemia. These results are consistent with our previous observations.

\section{Patients and Method}

Ninety patients with beta-thalassemia major ( 55 males and 35 females) with a mean age of 7.16 \pm 4.06 years (1-13 years), admitted to the Pediatric Department, Hematology Policlinic, University of Dicle, Faculty of Medicine were enrolled in this study. An age and sex matched control group of 60 healthy children (36 males and 24 females) with a mean age $6.98 \pm 3.66$ years (1-13 years) was also formed. Patients received a mean of $17.2 \pm 5.4$ transfusions over a period of 12 months, receiving an average of $7.6 \pm 2.4 \mathrm{~mL}$ red blood cells/kg per transfusion. All patients received blood transfusion and they were treated with chelation therapy using deferoxamine by subcutaneous infusion with a dose of $20-40 \mathrm{mg} / \mathrm{kg} / 24 \mathrm{hr}$ over $8-12 \mathrm{hr}$ via portable infusion device when their ferritin levels reach above $1000 \mathrm{ng} / \mathrm{mL}$. Parathyroid function and iron load status were evaluated by measurements of serum total parathyroid hormone (PTH), calcium (Ca), phosphorous (P), alkaline phosphatase (ALP), 25-hydroxyvitamin D (25-OHD) and ferritin levels.

Blood samples were taken from all patients at least 15 days after the transfusion, preferably after an overnight fasting on the transfusion day. Ca, P, ALP levels were measured from centrifuged venous blood by enzymatic colorimetric method performed with Abbot AEROSET instrument (Abbott Laboratories Inc., Abbott Park, IL, USA) at Biochemistry Laboratory. Serum ferritin levels were recorded on Roche Diagnostic E 170 analyzer (Roche Diagnostics 1010/2010, Mannheim, Germany) by Chemiluminescence's Immunoassay (ECLIA) method. Parathyroid hormone (PTH) was measured with Immulite 2000 auto-analyzer (Diagnostic Products Corporation, Los Angeles, CA, USA 90045-6900) using chemiluminescent method. 25-OHD levels were determined by High Pressure Liquid Chromatography (HPLC).

\section{Statistical Analyses}

Statistical analyses were carried out using the software packages SPSS 12.0 (SPSS, Inc., Chicago, USA) using Student's t-test, Chi-square test and Mann-Whitney U-test, and Pearson and Spearman correlation and regression analyses were applied in statistical evaluations. Statistical significance was accepted as $\mathrm{P}<0.05$. Results are expressed as mean \pm standard deviation (SD).

\section{Results}

All patients underwent comprehensive physical examination and they were questioned if they had any other complaints except beta-thalassemia at the time of presentation to the Hematology Polyclinic. The result of physical examination showed that none of the patients have had rachitism. A total 90 of patients were enrolled in the study, 35 of them (38.9\%) were female and 55 (61.1\%) of them were male. Mean age for females was $7.16 \pm 4.06$ years and for males was $7.61 \pm 4.26$ years.

Biochemical parameters (PTH, Ca, P, ALP, 25-OHD and ferritin) measured from serum of patients and healthy children are recorded in table 1. It shows that PTH $(\mathrm{P}<0.05)$ and ferritin $(\mathrm{P}<0.001)$ levels in thalassemia patients are higher than those in controls while 25-OHD $(\mathrm{P}<0.05)$ levels are lower than in those in control. The mean values for other parameters measured for patients are comparable to those obtained for the control group.

The correlations between studied parameters are presented as follows. It was found that ferritin was significantly correlated with PTH ( $\mathrm{P}=0.05)$, ALP $(\mathrm{P}=0.002), \mathrm{P}$ $(\mathrm{P}=0.001)$ and the age of patients $(\mathrm{P}=0.007)$ but it was not correlated with serum total $\mathrm{Ca}(\mathrm{P}>0.05)$. 


\begin{tabular}{|c|c|c|}
\hline Parameters & Averages & Reference Ranges \\
\hline $\mathrm{Ca}(\mathrm{mg} / \mathrm{dL})$ & $9.4 \pm 0.6$ & $8.4-10.2$ \\
\hline$P(\mathrm{mg} / \mathrm{dL})$ & $4.75 \pm 0.7$ & $2.7-4.5$ \\
\hline $\operatorname{ALP}(\mathrm{U} / \mathrm{L})$ & $167.1 \pm 68.2$ & $40-150$ \\
\hline PTH (pgl/mL) & $54.7 \pm 21.3$ & $15-65$ \\
\hline Ferritin (ng/mL) & $2702.6 \pm 1649.1$ & $13-150 \mathrm{ng} / \mathrm{mL}$ \\
\hline $25(\mathrm{OH})$ vitamin $D(\mu \mathrm{g} / \mathrm{L})$ & $24.95 \pm 5.82$ & $\begin{array}{c}\text { preferable }>40 \\
\text { subclinic deficiency }<40 \\
\text { insufficiency }<20 \\
\text { deficiency }<10\end{array}$ \\
\hline
\end{tabular}

Splenectomy was applied to 20 patients (22.2\%). The effect of splenectomy on parameters studied indicates that the application of splenectomy is significantly correlated with the age and PTH levels of patients. Those splenectomised have an average age and PTH level of $10.60 \pm 4.10$ and $63.89 \pm 19.83$ while the average values obtained for those not splenectomised are $6.60 \pm 3.38$ and $52.18 \pm 21.10$.

Mean Hemoglobin ( $\mathrm{Hb}$ ) levels before and after blood transfusions were reported as $8.7 \pm 0.6$ and $12.8 \pm 1.2 \mathrm{~g} / \mathrm{dl}$. This value was $13.3 \pm 1.4 \mathrm{~g} / \mathrm{dl}$ in the control group. The effect of blood transfusion frequency (BTF) on laboratory parameters was also investigated. It was found that BFT only influences ferritin levels. Those receiving blood transfusion every 3-4 weeks have higher ferritin levels $(3745 \pm 1926 \mathrm{ng} / \mathrm{ml})$ compared with those $(2008 \pm 946 \mathrm{ng} / \mathrm{ml})$ receiving transfusion every $4-12$ weeks $(\mathrm{P}=0.05)$. It was also seen that there is a correlation between the application of splenectomy and blood transfusion rate $(\mathrm{P}=0.05) .16$ out of 20 patients splenectomised received blood transfusion every 4-12 weeks while 4 out of 20 received blood transfusion every 3-4 weeks. It was also observed that there is no effect blood transfusion rate on the sex of patients

It was indicated that supplementary therapy has not a significant effect on biochemical parameters and the applications $(\mathrm{P}>0.05)$. It was also observed that there is no effect of the sex of patients on biochemical parameters and applications such as splenectomy, BTF and supplementary therapy.

\section{Discussion}

Parathyroid dysfunctions are thought to be a rare consequence of iron overload seen in beta-thalassemia and basically observed as hypoparathyroidism, accompanied by other endocrinopathies. It is usually thought as a late complication and occurs after the age of 16 years. In the few published studies, the prevalence varies greatly from very low to as high as $22.5 \%$ [8]. The largest study on endocrine problems in thalassemia published to date included 1861 patients from 25 centers, and it recorded hypoparathyroidism in $3.6 \%$ of patients (mean age at diagnosis 18.7 years), although the percentage varied from center to center [9]. Our study involved measurements of serum Ca, P, ALP, PTH and 25-OHD levels in 90 children with beta thalassemia major to assess parathyroid dysfunction in these patients. We found that low serum total calcium and phosphorous levels in $11(\% 12.2)$ and $4(4.44 \%)$ patients, respectively while high phosphorous and ALP levels in $2(2.22 \%)$ and in $6(6.6 \%)$ patients, respectively. Low PTH levels were not observed. Mean Ca value in patients was significantly lower than that in control $(\mathrm{P}<0.05)$ while mean $\mathrm{PTH}(\mathrm{P}<0.05)$ value was significantly higher than that in control (Table 1). Data in table 2 indicates that children with higher PTH levels have significantly higher serum ALP $(\mathrm{P}<0.01)$ and ferritin $(\mathrm{P}=0.05)$ levels but lower total $\mathrm{Ca}(\mathrm{P}<0.05)$ and serum 25-OHD $(\mathrm{P}<0.05)$ levels compared with those with normal PTH levels. It was found that there is a positive correlation between ferritin, and serum PTH. Hence hypoparathyroidism was not observed in these patients, which was ascribed to the ages of the patients (mostly under 10 years, 80\%) enrolled in the 


\begin{tabular}{|c|c|c|c|}
\hline Parameters & Number of Cases & Percentage (\%) & Values \\
\hline \multirow[t]{3}{*}{$\mathrm{Ca}(\mathrm{mg} / \mathrm{dL})$} & 11 & 12 & Low \\
\hline & 79 & 88 & Normal \\
\hline & -- & -- & High \\
\hline \multirow[t]{3}{*}{ PTH (pgl/mL) } & -- & -- & Low \\
\hline & 67 & 74.5 & Normal \\
\hline & 23 & 25.5 & High \\
\hline \multirow[t]{3}{*}{$P(\mathrm{mg} / \mathrm{dL})$} & 3 & 93.4 & Low \\
\hline & 3 & 3.3 & Normal \\
\hline & 84 & 3.3 & High \\
\hline \multirow[t]{3}{*}{$\operatorname{ALP}(\mathrm{U} / \mathrm{L})$} & -- & -- & Low \\
\hline & 84 & 93.4 & Normal \\
\hline & 6 & 6.6 & High \\
\hline \multirow[t]{4}{*}{$\mathrm{Fe}(\mathrm{ng} / \mathrm{mL})$} & 7 & 8 & $0-1000$ \\
\hline & 26 & 28.8 & $1000-2000$ \\
\hline & 42 & 46.6 & $2000-4000$ \\
\hline & 15 & 16.6 & $>4000$ \\
\hline \multirow[t]{4}{*}{$25(\mathrm{OH})$ vitamin $D(\mu \mathrm{g} / \mathrm{L})$} & -- & -- & preferable \\
\hline & 77 & 85.6 & subclinic deficiency \\
\hline & 13 & 14.4 & insufficiency \\
\hline & -- & -- & deficiency \\
\hline
\end{tabular}

study. A similar work was reported by Güler and co-workers, who also did not detect hypoparathyroidism in 23 cases, who were all under 15 years old, mostly under 10 years [10].

However, high PTH levels were found in 23 patients while 25-OHD levels, although it was taken during the summer, were low in all patients. It is known that 25-OHD deficiency and a raised PTH usually indicates secondary hyperparathyroidism unless there is concomitant primary or tertiary hyperparathyroidism. The development of secondary hyperparathyroidism related to the decrease in 25-OHD level may be attributed to the effect of iron collapsing in liver. Although most clinical signs of iron loading do not appear until the second decade of life in patients, evidence from serial liver biopsies in very young patients presents that the toxic effects of iron begins much earlier than this. After approximately one year of transfusions, iron starts to be accumulated in parenchymal tissues [11] where it may bring about substantial toxicity as compared with that within reticuloendothelial cells $[12,13]$. A report by De Vernejoul and co-workers showed that iron firstly collapses in liver and kidneys and thus the collapse of iron in liver will reduce the 25-hydroxylation of vitamin $\mathrm{D}$ and consequently a low levels of serum 1,25(OH)2D3 will be observed [14]. However, a report by Peacey illustrates that low 25-OHD does not affect the level of 1, 25(OH)2D [15]. The mean age of our patients was $7.17 \pm 3.7$ and the large population $(80 \%)$ was under 10 years. This indicates that iron would principally collapse in the liver before endocrine organelles in earlier period of life.

The reason why some patients develop parathyroid dysfunction and others do not is not exactly known. It is thought that parathyroid dysfunction is not always related to iron level, but to some other factors based on patient's individual tendency. A number of possible mechanisms have been described to be responsible for the damage of parathyroid glands through iron overload. These include free radical formation and lipid peroxidation resulting in mitochondrial, lysosomal and sarcolemmal membrane damage [16], and a number of surface transferrin receptors in the cell, and the 
ability of the cell to protect itself against inorganic iron [17]. In addition, the effect of splenectomy on parathyroid function was also considered to further evaluate parathyroid dysfunction in patients with beta-thalassemia major. It was found that splenectomised patients $(n=20)$ had higher PTH levels than not-splenectomised patients $(\mathrm{P}=0.49)$.

\section{Conclusion}

All the thalassemia patients with parathyroid dysfunction were above the age of 10 years except for one [9]. Thus, parathyroid dysfunction is primarily considered as a disease of the second or third decade. Our study produces evidence that parathyroid dysfunction in patients with thalassemia is frequent and it could be seen in the earlier stage of life. Therefore, parathyroid functions should be followed periodically in the earlier period of life in the patients with beta-thalassemia major.

\section{References}

1. Cooley TB, Lee P. A series of cases of splenomegaly in children with anemia and peculiar changes. Trans Am Pediatr Soc. 1925; 37: 29-30.

2. Saka N, Sukur M, Bundak R, Anak S, Neyzi $O$, et al. Growth and puberty in thalassemia major. J Pediatr Endocrinol Metab. 1995; 8: 181-186. Ref.: https://goo.gl/CfD5Da

3. Modell B, Letsky EA, Flynn DM, Peto R, Weatherall DJ. Survival and desferrioxamine in thalassemia major. BMJ. 1982; 284: 1081-1084. Ref.: https://goo.gl/c1pWcH

4. Al-Elq AH, Al-Seed HH. Endocrinopathies in patients with thalassemias. Saudi Med J. 2004; 25: 13471351. Ref.: https://goo.gl/F2LtFi

5. Vullo C, De Sanctis V, Katz M, Wonke B, Hoffbrand AV, et al. Endocrine abnormalities in thalassemia Ann NY Acad Sci. 1990; 612: 293-310. Ref.: https://goo.gl/2PgmVY

6. Pirinccioglu AG, Akpolat V, Gökalp D, Koksal $O$, Haspolat $K$, et al. Bone mineral density in children with beta-thalassemia major in Diyarbakir. Bone. 2011; 49: 819-823. Ref.: https://goo.gl/b7VXj5

7. Pirinccioglu AG, Deniz T, Gokalp D, Beyazit N, Haspolat K, et al. Assessment of Thyroid Function in Children Aged 1-13 Years with Beta-Thalassemia Major. Iranian J Pediatr. 2011; 21: 77-82. Ref.: https://goo.gl/y3pJp4

8. Perignon F, Brauner R, Souberbielle JC, de-Montalembert M, Girot R. Growth and endocrine function in major thalassemia. Arch Fr Pediatr. 1993; 50: 657-663. Ref.: https://goo.gl/ezSvnZ

9. Multicenter study of prevalence of endocrine complications in thalassaemia major. Italian Working Group On Endocrine Complications in Non-Endocrine Diseases. Clin Endocrinol (Oxf). 1994; 42: 581586. Ref.: https://goo.gl/hWWf9D

10. Güler E, Patıroğlu T, Çaksen H, Özdemir MA, Kurtoğlu S, et al. Talasemi Majörlü Vakalarda Endokrin Komplikasyonların Değerlendirilmesi. Turkish. 199; 34: 174-781. Ref.: https://goo.gl/jbXcZM

11. Risdon RA, Flynn DM, Barry M. The relation between liver iron concentration and liver damage in transfusional iron overload in thalassaemia and the effect of chelation therapy. Gut 1973; 14: 421. Ref.: https://goo.gl/8nq4JW

12. Hershko C, Weatherall DJ. Iron-chelating therapy. Crit Rev Clin Lab Sci 1988; 26: 303-345. Ref.: https://goo.gl/hoqTCH

13. Hershko C, Konijn AM, Link G. Iron chelators for thalassaemia. Br J Haematol 1998; 101: 399-406. https://goo.gl/ySg6hS

14. De Vernejoul MC, Girot K, Gueris J, Cancela L, Bang S,et al. Calcium phosphate metabolism and bone disease in patients with homozygous thalassaemia. J Clin Endocrinol Metab.1982; 54: 276281. Ref.: https://goo.gl/o2ae6d

15. Peacey SR, Routine biochemistry in suspected vitamin D deficiency. J R Soc Med. 2004; 97: 322-325. Ref.: https://goo.gl/xLjUeY

16. Gutteridge JM, Halliwell B. Iron toxicity and oxygen radicals. In: Hershko C, editor. Iron chelating therapy. London: Baillière Tindall, 1989; 2: 195-256. Ref.: https://goo.gl/h7fbJN

17. Iancu T. Ultrastructural pathology of iron overload with special reference to endocrine glands. In Pintor C, Corda R, De-Sanctis V, editors. Workshop on endocrine problems in thalassemia. Venezia: San Marco Scientific Publications. 1990: 19-28. 